\title{
Developmental cell biology of human villous trophoblast: current research problems
}

\author{
JOHN D. APLIN* \\ Maternal and Fetal Health Research Group, University of Manchester, UK
}

\begin{abstract}
The common gestational pathologies are placental and developmental in origin. However, much remains to be learned about the key events of morphogenesis and growth in the placenta. Metabolic settings established early in both the fetus and placenta define their capacity to respond to later challenges, as well as the quality of the response. Placental growth is exponential in the first trimester and involves coordinated events in trophoblast and mesenchyme, with early cell segregation events having a strong influence on growth potential. One of these is the differentiation of progenitor cytotrophoblasts into villous intermediate cells programmed to fuse with the syncytium, or, alternatively, into extravillous migratory cells that transform the maternal vascular supply. In the latter case, contact with decidual extracellular matrix stimulates differentiation, and therefore this decision is influenced by the number of contact sites at the placental periphery, which in turn is a function of branching in the villous tree. The villous trophoblast bilayer is the primary barrier between maternal and fetal tissues. The maternal-facing layer is syncytial and post-mitotic: this limits traffic of pathogens to the fetus and chimaerism arising by shedding of (non-proliferative) syncytial elements into maternal circulation. Conventional cell culture models fail to replicate this critical vectorial relationship. Tissue explants can overcome the problem to some extent, and have been used to show that turnover of trophoblast in the villous environment is regulated by signals from both fetal and maternal tissues. Maternally delivered insulin-like growth factors stimulate growth and might be therapeutically useful when endogenous growth pathways falter.
\end{abstract}

KEY WORDS: trophoblast, villus, proliferation, fusion, syncytium

\section{Introduction}

Trophoblast progenitor cells, trophoblast-mesenchymal interaction and the early origins of gestational pathology

There is wide agreement that the major pregnancy pathologies of first trimester miscarriage, pre-eclampsia (PE) and fetal growth restriction (FGR) result from skewing of placental development. In order to understand pathogenesis, develop effective and accurate approaches to prediction and eventually produce treatments, key developmental processes require to be delineated.

The purpose of the present article is to point to some unsolved problems in villous trophoblast developmental cell biology. An important limitation is that the definitive events of placental morphogenesis that follow closely after implantation are inaccessible to study (Aplin and Jones, 2008). It is of interest that human trophoblast can be obtained from embryonic stem cells either by selection after spontaneous differentiation in embryoid bodies
(Harun et al., 2006), or treatment with BMP4 (Chen et al., 2008; Schulz et al., 2008). These advances will make available cells representing earlier stages of placental development, and give rise to relevant lineages in vitro with greater fidelity than has hitherto been achieved.

It is important to recognise that early adjustments can be made to the blastocyst via altered cell allocation to trophectoderm or inner cell mass. In the early postimplantation stages, the extent of mesenchymal investment of the developing placenta is also likely to influence its final size. Global metabolic settings established early in placental development may also influence the later growth of the tissue; it is interesting in this regard that transcriptomic

\footnotetext{
Abbreviations used in this paper: $\mathrm{HIF}$, hypoxia-inducible factor; IGF, insulin-like growth factor; EGF, epidermal growth factor; FGR, fetal growth restriction; $\mathrm{PE}$, pre-eclampsia.
}

\footnotetext{
*Address correspondence to: John D Aplin. 5th Floor Research. St Mary's Hospital, Manchester M13 9WL, UK. Fax: +44-161-701-6971. e-mail: john.aplin@manchester.ac.uk
}

Final author-corrected PDF published online: 15 October 2009.

ISSN: Online 1696-3547, Print 0214-6282

(๑) 2009 UBC Press

Printed in Spain 
data in a variety of species distinguishes subsets of genes that have been coopted during evolution in support of either earlier or later stages of placental development (Knox and Baker, 2008). The realisation that pathways that would hitherto have been understood as 'immunological' contribute strongly to the development of the maternal-fetal interface (see Hunt et al., 2010; Bulmer et al., 2010) represents a paradigm shift, though it is readily explicable in evolutionary terms.

The focus here is on defining and evaluating current understanding of events occurring in trophoblast in the first trimester villus that might be linked to later-manifesting pathologies. These include proliferation, differentiation, fusion, and selected syncytial functional outputs, and the control of trophoblast functions by the combined effect of paracrine signals from mesenchyme or soluble signals from the maternal circulation. Brief consideration is given to decisions in the villous cytotrophoblast progenitor population that specify a syncytial or invasive fate; the behaviour of the invasive lineage is discussed in detail elsewhere in this volume (see Knoefler et al., 2010).

Improved insights, and testable hypotheses, should be achievable by studying developmental systems that, like the villous placenta, comprise epithelial and vascularised mesenchymal tissue. Thus, for example, one can recognise that the mechanisms giving rise to highly elaborated lung parenchyma (Metzger et al., 2008) require a type of branching morphogenesis that has features in common with placenta. Indeed, members of the sprouty protein family of FGF antagonists, which control branching morphogenesis in the lung, are found in placental stromal macrophages in all three trimesters (Anteby et al., 2005). The mechanisms whereby branching occurs during villous development, and the genes that control it, require experimental models that allow function to be tested (Cross et al., 2006). Branching as well as growth abnormalities may contribute to the altered villous morphology seen in some types of FGR (Jackson et al., 1995; Krebs et al., 1996; Macara et al., 1996; Mayhew et al., 2004).

Conversely, villous cytotrophoblast expresses factors that probably stimulate the development of the fetal stroma and fetoplacental vasculature (Demir et al., 2007). For example, these cells express VEGF from early gestation (Jackson et al., 1994), indicating the possibility of a paracrine role in angiogenesis (Challier etal., 2001). Thus bidirectional crosstalk between stroma and trophoblast is involved in placental development.

\section{Control of proliferation and differentiation}

\section{Villous cytotrophoblast as a syncytial progenitor}

The definitive human placenta has a continuous syncytium overlying a layer of cytotrophoblast that becomes progressively sparser as gestation advances (Jones and Fox, 1991). Villous cytotrophoblast contains a progenitor cell population that, all the way to term, continues to produce daughter cells that differentiate and fuse with the overlying syncytium (Jones and Fox, 1991), allowing expansion of syncytial surface area as well as replacement of material (membrane, cytoplasm and nuclei) that has been shed into the maternal circulation (Redman and Sargent, 2007). DNA synthesis occurs only in cytotrophoblasts; villous cytotrophoblast shows a mitotic index of approximately $1.5-2.9 \%$ in the period 6-9 weeks, and zero in the syncytium, which is exclusively post-mitotic (Chan et al., 1999; Kar et al., 2007). This arrange- ment protects the mother from chimaerism (though incompletely; see Gammill and Nelson, 2010) as the vast majority of nuclear material that is shed is not mitotically competent. It is significant that this phenomenon of a post-mitotic maternally-exposed layer of trophoblast seems to be shared by hemochorial placentas in many species.

Villous cytotrophoblast must undergo asymmetric cell divisions, each of which gives rise to a progenitor cell that maintains the pool, and another cell that differentiates to form an intermediate cytotrophoblast, before fusing with the overlying syncytium. This may follow a series of up to four symmetrical transit-amplifying divisions (Mayhew, 2001). Divisions occur laterally, that is, the mitotic spindle forms in the plane of the villous basement membrane (Kar et al., 2007) and suprabasal cytotrophoblast is not normally observed. To produce differentiated cells, a symmetrybreaking signal is required in advance of cytoplasmic polarisation, segregation of fate determinants and assembly of the mitotic spindle on the appropriate axis (Gonczy, 2008). The initiating signal remains unknown.

These considerations imply heterogeneity in the villous cytotrophoblast population at all stages of pregnancy. Indeed, TEM can clearly identify 'intermediate' or 'transitional' cells that are differentiated in preparation for fusion (Enders, 1965; Jones and Fox, 1991; Kar et al., 2007), and that express molecular markers including the transcription factor GCM-1 (Baczyk et al., 2004), caspases 8 and 10 (Black et al., 2004; Huppertz et al., 1999), FGFR2 (Baczyk et al., 2006) and the $\alpha$ subunit of chorionic gonadotrophin (Hoshina et al., 1982).

The cytotrophoblast pool increases with placental growth from 10-41 weeks but its volume fraction decreases, and, as growth of tissue surface area occurs, the cytotrophoblast layer alters from being relatively close-packed (indeed confluent in many places) in late first trimester to being rather sparse at term (Jones and Fox, 1991; Mayhew, 2001). The cells extend long thin processes laterally beneath the syncytium to create points of contact that can be seen in the electron microscope (Jones et al., 2008). At the same time the syncytium becomes thinner, again reflecting increased surface area. This growth in surface area occurs alongside stromal growth, and it is possible that the driving force (as for villous branching) resides in the mesenchymal compartment.

\section{Villous cytotrophoblast in vitro}

Cytotrophoblasts may be isolated from the villus at any stage of pregnancy for primary culture, but they quickly exit the mitotic cycle, differentiate and fuse to form a kind of giant cell that degenerates within about 5 days (Aplin and Crocker, 2007; Handwerger and Aronow, 2003; Kliman etal., 1986; Morrish etal., 1997). Though it is often assumed that this replicates the differentiation pathway of villous trophoblast, it is not clear to what extent such end-stage cells may resemble villous syncytium, or the giant cells of the placental bed, or are a cell culture artifact.

It has not proved possible to maintain proliferation of human primary trophoblast isolates in vitro (Morrish et al., 1997) though addition of EGF to highly purified term preparations can extend the proliferative lifespan of residual mononucleate cells beyond a week (Johnstone et al., 2005). Some literature is misleading on this point, as isolates may be contaminated with mesenchymallyderived cells that proliferate rapidly in vitro. A small proportion of such cells can skew measurements of thymidine or BrdU uptake 
if these are done without reliable phenotyping.

\section{Oxygen, HIF1 and cytotrophoblast regulation}

Factors in the three dimensional environment of the villus that are required to maintain progenitor cell characteristics in cytotrophoblast may include the subjacent mesenchyme and basement membrane, lateral adhesions to other cytotrophoblasts, and protection of the apical surface by syncytium. This last point is of interest in regard to the role of oxygen in regulating trophoblast proliferation. The discovery of a transition from low to higher oxygen concentration in the intervillous space at about 11 weeks (Foidart et al., 1992; Jauniaux et al., 2003) led to predictions that villous cytotrophoblast proliferation may be highly oxygen-dependent, but though there is a reduction in the mitotic index of cytotrophoblasts from 2.9 to 1.8 between 6 and 7 weeks of gestation (Kar et al., 2007), evidence in support of a step-change in proliferation at the time of the oxygen transition is so far lacking, and mitosis in villous cytotrophoblast, though slowing down (Challier et al., 2004), continues to term (Mayhew, 2001).

The oxygen-sensitive transcription factor HIF1 is an important regulator of placental development in mouse (Hickey and Simon, 2006) with direct effects on trophoblast fate (Cowden Dahl et al., 2005). However, even after exposure to $24 \mathrm{~h}$ of severe hypobaric hypoxia (6-7\% oxygen), pregnant mice do not express HIF1 $\alpha$ in the placental labyrinth unless nitric oxide synthase is also inhibited (Schaffer et al., 2006), though HIF is seen in less vascularised parts of the placenta. In tumour cell cultures, because of hydroxylation-dependent protein degradation, HIF1 $\alpha$ levels become elevated only when oxygen reaches levels below $1 \%$, whereas in human placenta, HIF1 $\alpha$ is expressed in early gestation (letta et al., 2006) when the ambient oxygen level in the intervillous space is estimated to be $2-3 \%$ (Jauniaux et al., 2003) but also at term when it is higher (Rajakumar and Conrad, 2000). The homologue HIF2 $\alpha$ is also present (Rajakumar and Conrad, 2000). Thus it appears that HIF may regulate transcription throughout gestation. However, the levels observed in placental homogenates are variable, undermining studies that have attempted to compare concentrations at various gestational stages or in normal and diseased (eg pre-eclamptic) tissues. HIF is strongly dependent on factors other than oxygen; for example, the glucose metabolites pyruvate and oxaloacetate inhibit HIF1 $\alpha$ protein degradation (Lu etal., 2005). The ambient oxygen concentration at the cytotrophoblast layer is unknown, though given the appreciable metabolic activity of the syncytial layer, it is clearly less than that found in the intervillous space. More precise, cell type-specific analysis of HIF levels and function are required.

\section{Explant models of villous cytotrophoblast}

The problems of loss of proliferation of primary cytotrophoblasts and their uncontrolled differentiation in vitrohave been addressed by the development of methods for maintaining villous tissue as explants (Miller et al., 2005). Here the normal vectorial relationship is preserved between mesenchyme, basement membrane and the trophoblast epithelium. In explanted first trimester tissue cytotrophoblast proliferation continues for at least several days at 6-20\% oxygen even in the absence of serum (Forbes et al., 2008). In term tissue, cytotrophoblast proliferation in explants is higher at $20 \%$ oxygen than $6 \%$, dropping to very low values at $1 \%$ (Heazell et al., 2008). Furthermore, blocking mitosis in cytotrophoblast in term explants promotes cell differentiation so that cell cycle withdrawal may in itself be a stimulus to differentiation (Crocker et al., 2007).

Proliferation in first trimester tissue can be increased at 4-5 weeks by supplying EGF (Maruo et al., 1992b) or IGF (Maruo et al., 1995), and from 8-12 weeks IGF1 or IGF2 (Forbes et al., 2008; Maruo et al., 1995) to the syncytial surface (ie from the 'maternal' side). IGF activates the MAP kinase pathway via the receptor IGFR1. Cytotrophoblast survival is also enhanced by IGF in a PI3 kinase-dependent process (Forbes et al., 2008).

This in turn raises questions about how signals delivered from maternal circulation might cross the mitotically inactive syncytium to stimulate villous cytotrophoblasts. If syncytium is removed using trypsin, basal proliferation ceases, indicating the importance of the overlying cell layer in regulating proliferation of progenitor cells. Exogenous IGF acting via IGFRI (Forbes et al., 2008), or FGF4 acting via FGFR2 (Baczyk et al., 2006), can directly stimulate proliferation of the exposed cytotrophoblasts. Thus it is possible that growth factors may be delivered from the syncytium to the underlying cytotrophoblast layer.

These observations suggest the possibility of rescuing undergrown placentas, and hence possibly fetuses, by means of growth factors supplied from maternal circulation. Such an approach should be targeted to avoid side effects in other maternal organs.

\section{Establishment of the extravillous cytotrophoblast lin- eage}

\section{First steps}

The villous cytotrophoblast population is also precursor to invasive extravillous cells. At sites of contact with the decidua, these proliferate to form anchoring sites containing cell columns in a plane perpendicular to the villous basement membrane, that eventually break away to infiltrate maternal tissues (Aplin et al., 1998). These extravillous precursor cells divide more than once as the cell column forms as indicated by the recognition of mitotic figures in suprabasal layers (Vicovac etal., 1995). The orientation of the mitotic spindle seems to be altered relative to the villous cytotrophoblast progenitor cells that differentiate to fuse with the syncytium. Cells entering the extravillous pathway lose contact with the villous basement membrane, a step that removes them from the progenitor cell niche and is likely to be of key importance in specifying this pathway. Thus it will be of interest to identify the factors that determine the orientation of the mitotic spindle and asymmetric segregation of cytoplasmic constituents prior to division.

\section{Modelling anchoring sites}

In explant culture these extravillous cells stay in cycle somewhat longer in $2 \%$ than $6 \%$ oxygen (Genbacev et al., 1997), although the effects on the numbers of cells populating the lineage are at best modest (Newby et al., 2005; Seeho et al., 2008). Bearing in mind the aforementioned data on villous cytotrophoblast proliferation, and the quite distinct 3D environments occupied by the villous and invasive cell populations, it is possible that oxygen effects are different in the two lineages. Exposure of pregnant rats to hypobaric hypoxia during early pregnancy (days 8.5-9.5) programs a later increase in the size of the junctional 
zone and increased endovascular trophoblast invasion in mid gestation (Seeho et al., 2008), perhaps indicating a lineagespecific effect.

\section{Potency of cytotrophoblast progenitors}

There remains the question of whether all villous cytotrophoblasts are bipotent, that is, retain the potential to differentiate both in the extravillous and villous lineages. When explants are set up in which villous trophoblast makes contact with a 3D extracellular matrix such as matrigel or collagen, extravillous-type outgrowths that resemble columns of extravillous cells arise from the villous tips (Aplin et al., 1999; Aplin etal., 1998; Bauer et al., 2004; Vicovac and Aplin, 1996). Furthermore, this activity is retained in first trimester villous tissue after culture under conditions in which the subsyncytial, non-tip cytotrophoblasts lose viability (James et al., 2005), and the resulting cells do not fuse (James et al., 2007). This might suggest that cytotrophoblasts at the tips are pre-determined extravillous cell precursors. However, villous tips arise by branching, and so as long as the placenta continues to undergo branching morphogenesis, cells at tips are derived from precursor cells previously situated at a nonbranching site. Thus, since the columns act as feeder sites for migratory extravillous trophoblast, the ultimate size of this population is a function of branching in the villous tree.

\section{The molecular basis of fusion}

\section{Progression of villous cytotrophoblast to intermediate sta- tus is required to acquire fusion competence}

One clear prediction arising from the hypothesis of asymmetric division in the villous cytotrophoblast is that one daughter cell should begin to express gene products that mediate fusion. Fusion occurs in an unregulated fashion in term trophoblast primary cultures, which advance spontaneously in vitro to fusion competence, while in first trimester primary cultures some fusion is observed. This suggests a progressive shift with gestation from a higher to a lower proportion of cells committed to the syncytial fate or, perhaps, that have advanced to intermediate status. Achieving full control of this transition in vitro remains an important research objective.

Numerous cell adhesion molecules expressed at the cytotrophoblast-syncytial interface are classically associated with epithelial junctions (cadherins, tight junction proteins, and others; Aplin et al., 2009). However there is so far only limited evidence for alterations in their distribution or abundance to coincide with differentiation or fusion. Several gene products that are expressed in villous trophoblast have been shown to be capable of mediating cell-cell fusion in cell lines. These include ADAM12 and the endogenous retroviral envelope proteins syncytin 1 and 2 (Huppertz et al., 2006a). Syncytin 2 is in villous cytotrophoblast (Kudaka et al., 2008; Malassine et al., 2007) while syncytin 1 is regulated by GCM-1 (Lin et al., 2005) and probably arises in intermediate cytotrophoblasts in advance of fusion, as well as being expressed in the syncytium (Huppertz et al., 2006a; Mi et al., 2000; Smallwood et al., 2003). Ultrastructural observations have implicated lysosomal enzymes in fusion (Contractor et al., 1977).

Once this has been accomplished there is a need to dispose of excess membrane. Fragments of membrane are visible in the syncytioplasm near sites of fusion (Contractor et al., 1977) and it is not clear whether this material is then broken down in lysosomes, recycled or transferred to the apical syncytial microvillous membrane (MVM) prior to shedding. Curiously, numerous adhesion molecules (cadherins, tight junction proteins, integrins; Aplin et al., 2009) thought to function in cytotrophoblast-cytotrophoblast adhesion appear in the MVM where their function is unclear.

\section{Syncytial function}

\section{Post-fusion maturation, nuclear condensation, aggregation, apoptosis and particle shedding}

The syncytium is a barrier to pathogens and maternal cells, a glycoprotein factory and secretory compartment, and a transporting epithelium (see Desforges and Sibley, 2010). Estimates suggest that cytotrophoblast nuclei that become incorporated into the syncytium spend some 3 weeks therein before becoming sloughed into maternal circulation, where fetal DNA comprises as much as $5 \%$ of the total. Their morphology ranges from large and rich in euchromatin (similar to intermediate cytotrophoblast), to highly condensed and fragmenting structures reminiscent of apoptotic bodies (Huppertz et al., 2006b; Jones and Fox, 1991). Therefore, during their time in the syncytium, nuclei probably undergo a change from active to inactive and eventually degenerative forms. Later in pregnancy, lateral redistribution of nuclei leads to clustering at thicker areas known as syncytial knots, with sparse ER and an apical membrane with relatively few microvilli. Other areas of syncytium exhibit an apical microvillous membrane where there is probably active transport across a thinner syncytioplasm with sparser nuclei and more synthetic and secretory apparatus. Cytoskeletal activity is likely to be required for this process. Crosslinking of actin by tissue transglutaminase prevents actin from depolymerising, and may play a role in stabilising domains within the syncytium in preparation for shedding (Robinson et al., 2007).

The observation that caspase 8 is activated in pre-fusion cytotrophoblasts (Gauster et al., 2009) has led to a hypothesis that apoptotic machinery is delivered at fusion into syncytium (Huppertz et al., 2006b). There are clear lateral variations in the abundance of apoptotic markers such as the cytokeratin 8 cleavage product known as M13 in the syncytioplasm, and evidence that syncytial knots harbour both M13 and fragmenting nuclei. However nuclei have been estimated to reside in the syncytium for 3-4 weeks before shedding, implying that condensation and degradation are arrested after fusion, presumably allowing these nuclei a period of transcriptional function, before the nuclear apoptotic cascade is reactivated. Rough endoplasmic reticulum, polysomes, and mitochondria are relatively less abundant in syncytial knots (Jones and Fox, 1991).

\section{Transcription and translation in syncytium}

Glycoproteins produced in large quantities in the syncytium include chorionic gonadotrophin (CG), chorionic somatomammotropin (CS, also known as placental lactogen) and pregnancy-specific glycoprotein (PSG). In situhybridisation studies show that mRNA encoding the $\mathrm{CG} \alpha$ subunit is expressed in intermediate cytotrophoblasts as well as in syncytium, while CS is mostly in syncytium (Hoshina et al., 1982). A detailed analysis of the $\mathrm{CG} \alpha$ promoter has suggested that transcriptional control 
may utilise different factors in the syncytium than in cytotrophoblast (Knofler et al., 2000). Thus phosphorylated CREB-1 and ATF-1 (dependent on protein kinase A), which bind cAMP response elements, and the coactivator $\mathrm{CBP}$, are primarily located in syncytial nuclei, suggesting the presence therein of transcriptional complexes (Knofler et al., 2000). AP-2 $\alpha$ levels also increase in differentiating cytotrophoblasts and there is in vitroevidence to show that it regulates a programme of gene expression that does not involve fusion but rather other aspects of syncytial function including the production of PSG and CG (Cheng et al., 2004). Cytotrophoblasts in placenta prior to 6 weeks express both CS and CG (Maruo et al., 1992a), including a hyperglycosylated form of $C G$ that is postulated to have distinct autocrine functions (Cole and Khanlian, 2007).

PSG polypeptide is exclusively syncytial in late first trimester, and ultrastructural immunolocalisation places it in rough ER, Golgi and secretory vesicles (Zhou et al., 1997). Indeed large amounts of these organelles must be produced in the syncytium to mediate protein production, glycosylation and transit. By analogy with other secretory cells, this may rely on the unfolded protein response (UPR) by which feedback from the ER reaches the nucleus to activate the gene network that produces an expanded protein biosynthetic and secretory compartment (Malhotra and Kaufman, 2007).

The syncytium also produces growth factors; mRNA encoding a soluble splice variant of the VEGF receptor known as sFlt1-14 has surprisingly been localised to syncytial knots at term (Sela et al., 2008), suggesting that some specific transcriptional activity may be needed at these loci.

Though it has been suggested that transcriptional rates are low in syncytium (Huppertz et al., 2006a), and it may very well be that mRNA delivered from intermediate cells at fusion contributes to the total template, it is clear that transcription also occurs within the syncytium (Ellery et al., 2009). Other transcription factors that have been identified in this compartment include Hash-2, I-mfa and Alf-1/HEB (Meinhardt et al., 2005). There is likely to be a role for microRNA (miRNA) in trophoblast differentiation but this remains to be unravelled (Donker et al., 2007).

\section{Conclusions}

\section{Trophoblast development and function are dependent on both maternal and fetal signals}

Syncytiotrophoblast is a challenging tissue to interrogate. Mouse models are limited; though the murine placenta exhibits a transporting epithelium that contains two layers of syncytiotrophoblast, current evidence indicates that these originate as independent founder cell populations, fusing laterally as villous development proceeds in the labyrinth (Simmons et al., 2008). In contrast, the human villous epithelium differentiates 'vertically' with progenitor cells that are distributed throughout the villous tree producing daughters that populate the overlying syncytium. In vitro, the giant multinucleated masses that result from fusion of primary human cytotrophoblast cultures are of limited lifespan, do not form a confluent layer that is amenable to permeability or transport studies, and lack the stromal support to create a polarised epithelium. The cell cycle exit and unregulated differentiation seen in primary cytotrophoblast cultures may be the result of the loss of an overlying adherent, metabolically active syncytium.
Human villous explant cultures in which cytotrophoblast progenitor cells continue to proliferate and fuse offer an alternative model (Forbes et al., 2008) in which the vectorial relationships are retained between cytotrophoblast, the underlying basement membrane and mesenchyme, and the overlying syncytium. This has revealed that turnover of trophoblast in the villous environment is regulated by signals from both fetal and maternal tissues.

\section{References}

ANTEBY, E.Y., NATANSON-YARON, S., GREENFIELD, C., GOLDMAN-WOHL, D., HAIMOV-KOCHMAN, R., HOLZER, H. and YAGEL, S. (2005). Human placental Hofbauer cells express sprouty proteins: a possible modulating mechanism of villous branching. Placenta 26: 476-483.

APLIN, J.D., HAIGH, T., JONES, C.J., CHURCH, H.J. and VICOVAC, L. (1999). Development of cytotrophoblast columns from explanted first-trimester human placental villi: role of fibronectin and integrin alpha5beta1. Biol Reprod60: 828838.

APLIN, J.D., JONES, C.J. and HARRIS, L.K. (2009). Adhesion molecules in human trophoblast - a review. I. Villous trophoblast. Placenta 30: 293-298.

APLIN, J.D., HAIGH, T., VICOVAC, L., CHURCH, H.J. and JONES, C.J. (1998). Anchorage in the developing placenta: an overlooked determinant of pregnancy outcome? Hum Fertil (Camb) 1: 75-79.

APLIN, J.D. and CROCKER, I.P. (2007). In vitromodels in pre-eclampsia research. In Pre-eclampsia - aetiology and clinical practice, (ed. F, L. and M, B.). Cambridge University Press, Cambridge, pp. 37-49.

APLIN, J.D. and JONES, C.J. (2008). Human placental development. In The Endometrium: molecular, cellular and clinical perspectives, (ed. APLIN, J. D.FAZLEABAS, A. T.GLASSER, S. R. and GIUDICE, L. C.). Informa Healthcare, London, pp. 441-453.

BACZYK, D., DUNK, C., HUPPERTZ, B., MAXWELL, C., REISTER, F., GIANNOULIAS, D. and KINGDOM, J.C. (2006). Bi-potential behaviour of cytotrophoblasts in first trimester chorionic villi. Placenta 27: 367-374.

BACZYK, D., SATKUNARATNAM, A., NAIT-OUMESMAR, B., HUPPERTZ, B., CROSS, J.C. and KINGDOM, J.C. (2004). Complex patterns of GCM1 mRNA and protein in villous and extravillous trophoblast cells of the human placenta. Placenta 25: 553-559.

BAUER, S., POLLHEIMER, J., HARTMANN, J., HUSSLEIN, P., APLIN, J.D. and KNOFLER, M. (2004). Tumor necrosis factor-alpha inhibits trophoblast migration through elevation of plasminogen activator inhibitor-1 in first-trimester villous explant cultures. J Clin Endocrinol Metab 89: 812-822.

BLACK, S., KADYROV, M., KAUFMANN, P., UGELE, B., EMANS, N. and HUPPERTZ, B. (2004). Syncytial fusion of human trophoblast depends on caspase 8. Cell Death Differ 11: 90-98.

BULMER, J.N., WILLIAMS, P.J. and LASH, G.E. (2010). Immune cells in the placental bed. Int. J. Dev. Biol. 54: 281-294 (doi: 10.1387/ijdb.082763jb)

CHALLIER, J.C., CARBILLON, L., KACEMI, A., VERVELLE, C., BINTEIN, T., GALTIER, M., ESPIE, M.J. and UZAN, S. (2001). Characterization of first trimester human fetal placental vessels using immunocytochemical markers. Cell Mol Biol (Noisy-le-grand) 47 Online Pub: OL79-87.

CHALLIER, J.C., LANDI, M., GALTIER, M., BINTEIN, T., CORTEZ, A. and RABREAU, M. (2004). Separation of trophoblastic and vascular cell lineages and vascular maturation in early human placental development. Cel/ Mol Biol (Noisy-le-grand) 50 Online Pub: OL527-OL531.

CHAN, C.C., LAO, T.T. and CHEUNG, A.N. (1999). Apoptotic and proliferative activities in first trimester placentae. Placenta 20: 223-227.

CHEN, G., YE, Z., YU, X., ZOU, J., MALI, P., BRODSKY, R.A. and CHENG, L. (2008). Trophoblast differentiation defect in human embryonic stem cells lacking PIG-A and GPI-anchored cell-surface proteins. Cel/ Stem Cel/2: 345355.

CHENG, Y.H., ARONOW, B.J., HOSSAIN, S., TRAPNELL, B., KONG, S. and HANDWERGER, S. (2004). Critical role for transcription factor AP-2alpha in human trophoblast differentiation. Physiol Genomics 18: 99-107.

COLE, L.A. and KHANLIAN, S.A. (2007). Hyperglycosylated hCG: a variant with separate biological functions to regular hCG. Mol Cel/ Endocrino/260-262: 228- 
236.

CONTRACTOR, S.F., BANKS, R.W., JONES, C.J. and FOX, H. (1977). A possible role for placental lysosomes in the formation of villous syncytiotrophoblast. Cell Tissue Res 178: 411-419.

COWDEN DAHL, K.D., FRYER, B.H., MACK, F.A., COMPERNOLLE, V., MALTEPE, E., ADELMAN, D.M., CARMELIET, P. and SIMON, M.C. (2005). Hypoxiainducible factors 1 alpha and 2alpha regulate trophoblast differentiation. $\mathrm{MO}$ Cell Bio/25: 10479-10491.

CROCKER, I.P., ARTHUR, P., HEAZELL, A.E. and BAKER, P.N. (2007). The mitotic manipulation of cytotrophoblast differentiation in vitro. Placenta28: 408411.

CROSS, J.C., NAKANO, H., NATALE, D.R., SIMMONS, D.G. and WATSON, E.D. (2006). Branching morphogenesis during development of placental villi. Differentiation 74: 393-401.

DEMIR, R., SEVAL, Y. and HUPPERTZ, B. (2007). Vasculogenesis and angiogenesis in the early human placenta. Acta Histochem 109: 257-265.

DESFORGES, M. and SIBLEY, C.P. (2010). Placental nutrient supply and fetal growth. Int. J. Dev. Biol. 54: 377-390 (doi: 10.1387/ijdb.082765md).

DONKER, R.B., MOUILLET, J.F., NELSON, D.M. and SADOVSKY, Y. (2007). The expression of Argonaute2 and related microRNA biogenesis proteins in normal and hypoxic trophoblasts. Mol Hum Reprod 13: 273-279.

ELLERY, P.M., CINDROVA-DAVIES, T., JAUNIAUX, E., FERGUSON-SMITH, A.C. and BURTON, G.J. (2009). Evidence for transcriptional activity in the syncytiotrophoblast of the human placenta. Placenta 30: 329-34.

ENDERS, A.C. (1965). Formation of Syncytium from Cytotrophoblast in the Human Placenta. Obstet Gyneco/25: 378-386.

FOIDART, J.M., HUSTIN, J., DUBOIS, M. and SCHAAPS, J.P. (1992). The human placenta becomes haemochorial at the 13th week of pregnancy. Int J Dev Biol 36: $451-453$

FORBES, K., WESTWOOD, M., BAKER, P.N. and APLIN, J.D. (2008). Insulin-like growth factor I and II regulate the life cycle of trophoblast in the developing human placenta. Am J Physiol Cell Physio/294: C1313-C1322.

GAMMILL H.S. and NELSON, J.L. (2010) Naturally acquired microchimerism. Int. J. Dev. Biol. 54: 531-543 (doi: 10.1387/ijdb.082767hg).

GAUSTER, M., SIWETZ, M. and HUPPERTZ B. (2009). Fusion of villous trophoblast can be visualized by localizing active caspase 8. Placenta 30: 547-550.

GENBACEV, O., ZHOU, Y., LUDLOW, J.W. and FISHER, S.J. (1997). Regulation of human placental development by oxygen tension. Science 277: 1669-1672.

GONCZY, P. (2008). Mechanisms of asymmetric cell division: flies and worms pave the way. Nat Rev Mol Cell Bio/9: 355-366.

HANDWERGER, S. and ARONOW, B. (2003). Dynamic changes in gene expression during human trophoblast differentiation. Recent Prog Horm Res 58: 263281.

HARUN, R., RUBAN, L., MATIN, M., DRAPER, J., JENKINS, N.M., LIEW, G.C., ANDREWS, P.W., LI, T.C., LAIRD, S.M. and MOORE, H.D. (2006). Cytotrophoblast stem cell lines derived from human embryonic stem cells and their capacity to mimic invasive implantation events. Hum Reprod 21: 1349-1358.

HEAZELL, A.E., LACEY, H.A., JONES, C.J., HUPPERTZ, B., BAKER, P.N. and CROCKER, I.P. (2008). Effects of oxygen on cell turnover and expression of regulators of apoptosis in human placental trophoblast. Placenta 29: 175-186.

HICKEY, M.M. and SIMON, M.C. (2006). Regulation of angiogenesis by hypoxia and hypoxia-inducible factors. Curr Top Dev Bio/76: 217-257.

HOSHINA, M., BOOTHBY, M. and BOIME, I. (1982). Cytological localization of chorionic gonadotropin alpha and placental lactogen mRNAs during development of the human placenta. J Cel/ Bio/93: 190-198.

HUNT, J.S., PACE, J.L. and GILL, R.M. (2010) Immunoregulatory molecules in human placentas: potential for diverse roles in pregnancy. Int. J. Dev. Biol. 54: 457-467 (doi: 10.1387/ijdb.082831jh)

HUPPERTZ, B., BARTZ, C. and KOKOZIDOU, M. (2006a). Trophoblast fusion: fusogenic proteins, syncytins and ADAMs, and other prerequisites for syncytial fusion. Micron 37: 509-517.

HUPPERTZ, B., FRANK, H.G., REISTER, F., KINGDOM, J., KORR, H. and KAUFMANN, P. (1999). Apoptosis cascade progresses during turnover of human trophoblast: analysis of villous cytotrophoblast and syncytial fragments in vitro. Lab Invest79: 1687-1702.
HUPPERTZ, B., KADYROV, M. and KINGDOM, J.C. (2006b). Apoptosis and its role in the trophoblast. Am J Obstet Gyneco/ 195: 29-39.

IETTA, F., WU, Y., WINTER, J., XU, J., WANG, J., POST, M. and CANIGGIA, I. (2006). Dynamic HIF1A regulation during human placental development. Biol Reprod 75: 112-121.

JACKSON, M.R., CARNEY, E.W., LYE, S.J. and RITCHIE, J.W. (1994). Localization of two angiogenic growth factors (PDECGF and VEGF) in human placentae throughout gestation. Placenta 15: 341-353.

JACKSON, M.R., WALSH, A.J., MORROW, R.J., MULLEN, J.B., LYE, S.J. and RITCHIE, J.W. (1995). Reduced placental villous tree elaboration in small-forgestational-age pregnancies: relationship with umbilical artery Doppler waveforms. Am J Obstet Gynecol 172: 518-525.

JAMES, J.L., STONE, P.R. and CHAMLEY, L.W. (2005). Cytotrophoblast differentiation in the first trimester of pregnancy: evidence for separate progenitors of extravillous trophoblasts and syncytiotrophoblast. Reproduction 130: 95-103.

JAMES, J.L., STONE, P.R. and CHAMLEY, L.W. (2007). The isolation and characterization of a population of extravillous trophoblast progenitors from first trimester human placenta. Hum Reprod 22: 2111-2119.

JAUNIAUX, E., GULBIS, B. and BURTON, G.J. (2003). The human first trimester gestational sac limits rather than facilitates oxygen transfer to the foetus-a review. Placenta 24 Suppl A: S86-S93.

JOHNSTONE, E.D., SIBLEY, C.P., LOWEN, B. and GUILBERT, L.J. (2005). Epidermal growth factor stimulation of trophoblast differentiation requires MAPK11/14 (p38 MAP kinase) activation. Biol Reprod73: 1282-1288.

JONES, C.J. and FOX, H. (1991). Ultrastructure of the normal human placenta Electron Microsc Rev 4: 129-178.

JONES, C.J., HARRIS, L.K., WHITTINGHAM, J., APLIN, J.D. and MAYHEW, T.M. (2008). A re-appraisal of the morphophenotype and basal lamina coverage of cytotrophoblasts in human term placenta. Placenta 29: 215-219.

KAR, M., GHOSH, D. and SENGUPTA, J. (2007). Histochemical and morphological examination of proliferation and apoptosis in human first trimester villous trophoblast. Hum Reprod 22: 2814-2823.

KLIMAN, H.J., NESTLER, J.E., SERMASI, E., SANGER, J.M. and STRAUSS, J.F., 3RD. (1986). Purification, characterization, and in vitro differentiation of cytotrophoblasts from human term placentae. Endocrinology 118: 1567-1582.

KNOFLER, M., SALEH, L., BAUER, S., VASICEK, R., GRIESINGER, G. STROHMER, H., HELMER, H. and HUSSLEIN, P. (2000). Promoter elements and transcription factors involved in differentiation-dependent human chorionic gonadotrophin-alpha messenger ribonucleic acid expression of term villous trophoblasts. Endocrinology 141: 3737-3748.

KNOFLER, M. (2010) Critical growth factors and signalling pathways controlling human trophoblast invasion. Int. J. Dev. Biol. 54: 269-280 (doi: 10.1387/ ijdb.082769mk).

KNOX, K. and BAKER, J.C. (2008). Genomic evolution of the placenta using cooption and duplication and divergence. Genome Res 18: 695-705.

KREBS, C., MACARA, L.M., LEISER, R., BOWMAN, A.W., GREER, I.A. and KINGDOM, J.C. (1996). Intrauterine growth restriction with absent end-diastolic flow velocity in the umbilical artery is associated with maldevelopment of the placental terminal villous tree. Am J Obstet Gyneco/175: 1534-1342.

KUDAKA, W., ODA, T., JINNO, Y., YOSHIMI, N. and AOKI, Y. (2008). Cellular localization of placenta-specific human endogenous retrovirus (HERV) transcripts and their possible implication in pregnancy-induced hypertension. Placenta 29: 282-289.

LIN, C., LIN, M. and CHEN, H. (2005). Biochemical characterization of the human placental transcription factor GCMa/1. Biochem Cel/ Bio/83: 188-195.

LU, H., DALGARD, C.L., MOHYELDIN, A., MCFATE, T., TAIT, A.S. and VERMA, A. (2005). Reversible inactivation of HIF-1 prolyl hydroxylases allows cell metabolism to control basal HIF-1. J Biol Chem 280: 41928-41939.

MACARA, L., KINGDOM, J.C., KAUFMANN, P., KOHNEN, G., HAIR, J., MORE, I.A., LYALL, F. and GREER, I.A. (1996). Structural analysis of placental terminal villi from growth-restricted pregnancies with abnormal umbilical artery Dopple waveforms. Placenta 17: 37-48.

MALASSINE, A., BLAISE, S., HANDSCHUH, K., LALUCQUE, H., DUPRESSOIR A., EVAIN-BRION, D. and HEIDMANN, T. (2007). Expression of the fusogenic HERV-FRD Env glycoprotein (syncytin 2) in human placenta is restricted to villous cytotrophoblastic cells. Placenta 28: 185-191. 
MALHOTRA, J.D. and KAUFMAN, R.J. (2007). The endoplasmic reticulum and the unfolded protein response. Semin Cell Dev Biol18: 716-731.

MARUO, T., LADINES-LLAVE, C.A., MATSUO, H., MANALO, A.S. and MOCHIZUKI, M. (1992a). A novel change in cytologic localization of human chorionic gonadotropin and human placental lactogen in first-trimester placenta in the course of gestation. Am J Obstet Gyneco/167: 217-222.

MARUO, T., MATSUO, H., MURATA, K. and MOCHIZUKI, M. (1992b). Gestational age-dependent dual action of epidermal growth factor on human placenta early in gestation. J Clin Endocrinol Metab 75: 1362-1367.

MARUO, T., MURATA, K., MATSUO, H., SAMOTO, T. and MOCHIZUKI, M. (1995). Insulin-like growth factor-I as a local regulator of proliferation and differentiated function of the human trophoblast in early pregnancy. Early Pregnancy 1:54-61.

MAYHEW, T.M. (2001). Villous trophoblast of human placenta: a coherent view of its turnover, repair and contributions to villous development and maturation. Histol Histopathol 16: 1213-1224.

MAYHEW, T.M., WIJESEKARA, J., BAKER, P.N. and ONG, S.S. (2004). Morphometric evidence that villous development and fetoplacental angiogenesis are compromised by intrauterine growth restriction but not by pre-eclampsia. Placenta 25: 829-833.

MEINHARDT, G., HUSSLEIN, P. and KNOFLER, M. (2005). Tissue-specific and ubiquitous basic helix-loop-helix transcription factors in human placental trophoblasts. Placenta 26: 527-539.

METZGER, R.J., KLEIN, O.D., MARTIN, G.R. and KRASNOW, M.A. (2008). The branching programme of mouse lung development. Nature 453: 745-750.

MI, S., LEE, X., LI, X., VELDMAN, G.M., FINNERTY, H., RACIE, L., LAVALLIE, E., TANG, X.Y., EDOUARD, P., HOWES, S. et al. (2000). Syncytin is a captive retroviral envelope protein involved in human placental morphogenesis. Nature 403: 785-789.

MILLER, R.K., GENBACEV, O., TURNER, M.A., APLIN, J.D., CANIGGIA, I. and HUPPERTZ, B. (2005). Human placental explants in culture: approaches and assessments. Placenta 26: 439-448.

MORRISH, D.W., DAKOUR, J., LI, H., XIAO, J., MILLER, R., SHERBURNE, R., BERDAN, R.C. and GUILBERT, L.J. (1997). In vitro cultured human term cytotrophoblast: a model for normal primary epithelial cells demonstrating a spontaneous differentiation programme that requires EGF for extensive development of syncytium. Placenta 18: 577-585.

NEWBY, D., MARKS, L. and LYALL, F. (2005). Dissolved oxygen concentration in culture medium: assumptions and pitfalls. Placenta 26: 353-357.

RAJAKUMAR, A. and CONRAD, K.P. (2000). Expression, ontogeny, and regulation of hypoxia-inducible transcription factors in the human placenta. Biol Reprod
63: $559-569$

REDMAN, C.W. and SARGENT, I.L. (2007). Microparticles and immunomodulation in pregnancy and pre-eclampsia. J Reprod Immuno/76: 61-67.

ROBINSON, N.J., BAKER, P.N., JONES, C.J. and APLIN, J.D. (2007). A role for tissue transglutaminase in stabilization of membrane-cytoskeletal particles shed from the human placenta. Biol Reprod77: 648-657.

SCHAFFER, L., VOGEL, J., BREYMANN, C., GASSMANN, M. and MARTI, H.H. (2006). Preserved placental oxygenation and development during severe systemic hypoxia. Am J Physiol Regul Integr Comp Physio/290: R844-R851.

SCHULZ, L.C., EZASHI, T., DAS, P., WESTFALL, S.D., LIVINGSTON, K.A. and ROBERTS, R.M. (2008). Human embryonic stem cells as models for trophoblast differentiation. Placenta 29 Suppl A: S10-S16.

SEEHO, S.K., PARK, J.H., ROWE, J., MORRIS, J.M. and GALLERY, E.D. (2008). Villous explant culture using early gestation tissue from ongoing pregnancies with known normal outcomes: the effect of oxygen on trophoblast outgrowth and migration. Hum Reprod 23: 1170-1179.

SELA, S., ITIN, A., NATANSON-YARON, S., GREENFIELD, C., GOLDMANWOHL, D., YAGEL, S. and KESHET, E. (2008). A novel human-specific soluble vascular endothelial growth factor receptor 1: cell type-specific splicing and implications to vascular endothelial growth factor homeostasis and preeclampsia. Circ Res 102: 1566-1574.

SIMMONS, D.G., NATALE, D.R., BEGAY, V., HUGHES, M., LEUTZ, A. and CROSS, J.C. (2008). Early patterning of the chorion leads to the trilaminar trophoblast cell structure in the placental labyrinth. Development 135: 20832091.

SMALLWOOD, A., PAPAGEORGHIOU, A., NICOLAIDES, K., ALLEY, M.K., JIM A., NARGUND, G., OJHA, K., CAMPBELL, S. and BANERJEE, S. (2003). Temporal regulation of the expression of syncytin (HERV-W), maternally imprinted PEG10, and SGCE in human placenta. Biol Reprod69: 286-293.

VICOVAC, L. and APLIN, J.D. (1996). Epithelial-mesenchymal transition during trophoblast differentiation. Acta Anat (Basel) 156: 202-216.

VICOVAC, L., JONES, C.J. and APLIN, J.D. (1995). Trophoblast differentiation during formation of anchoring villi in a model of the early human placenta in vitro. Placenta 16: 41-56

ZHOU, G.Q., BARANOV, V., ZIMMERMANN, W., GRUNERT, F., ERHARD, B. MINCHEVA-NILSSON, L., HAMMARSTROM, S. and THOMPSON, J. (1997). Highly specific monoclonal antibody demonstrates that pregnancy-specific glycoprotein (PSG) is limited to syncytiotrophoblast in human early and term placenta. Placenta 18: 491-501. 


\section{Further Related Reading, published previously in the Int. J. Dev. Biol.}

See our recent Special Issue Epigenetics \& Development edited by Saadi Khochbin and Stefan Nonchev at: http://www.ijdb.ehu.es/web/contents.php?vol=53\&issue=2-3

See Special Issue Pattern Formation edited by Michael K. Richardson and Cheng-Ming Chuong at: http://www.ijdb.ehu.es/web/contents.php?vol=53\&issue=5-6

Trisomy 21- affected placentas highlight prerequisite factors for human trophoblast fusion and differentiation André Malassiné, Jean-Louis Frendo and Danièle Evain-Brion Int. J. Dev. Biol. (2010) 54: 475-482 (doi: 10.1387/ijdb.082766am)

The influence of the intrauterine environment on human placental development Graham J. Burton, Eric Jauniaux and D. Stephen Charnock-Jones Int. J. Dev. Biol. (2010) 54: 303-312 (doi: 10.1387/ijdb.082764gb)

Puzzles of mammalian fertilization - and beyond J. Michael Bedford Int. J. Dev. Biol. (2008) 52: 415-426

An activating mutation in the PDGF receptor-beta causes abnormal morphology in the mouse placenta

Camilla Looman, Tong Sun, Yang Yu, Agata Zieba, Aive Ahgren, Ricardo Feinstein, Henrik Forsberg, Carina Hellberg, Carl-Henrik Heldin, Xiao-Qun Zhang, Karin Forsberg-Nilsson, Nelson Khoo, Reinald Fundele and Rainer Heuchel Int. J. Dev. Biol. (2007) 51: 361-370

A simple in vivo approach to investigate invasive trophoblast cells Juan A. Arroyo, Toshihiro Konno, Darya C. Khalili and Michael J. Soares Int. J. Dev. Biol. (2005) 49: 977-980

Control of reproduction by Polycomb Group complexes in animals and plants Anne-Elisabeth Guitton and Frederic Berger Int. J. Dev. Biol. (2005) 49: 707-716

Commitment of hematopoietic stem cells in avian and mammalian embryos: an ongoing story

Françoise Dieterlen-Lièvre

Int. J. Dev. Biol. (2005) 49: 125-130

Dynamic readjustment of parental methylation patterns of the 5'-flank of the mouse $\mathrm{H} 19$ gene during in vitro organogenesis.

L Liang, C Kanduri, M Pilartz, K Svensson, J H Song, P Wentzel, U Eriksson and R Ohlsson Int. J. Dev. Biol. (2000) 44: 785-790

Met signaling mutants as tools for developmental studies.

C Ponzetto, G Panté, C Prunotto', A leraci and F Maina

Int. J. Dev. Biol. (2000) 44: 645-653

Multiple functions of DIx genes.

G R Merlo, B Zerega, L Paleari, S Trombino, S Mantero and G Levi

Int. J. Dev. Biol. (2000) 44: 619-626

Changes in the placenta and in the rat embryo caused by the demethylating agent 5azacytidine.

M Vlahovic, F Bulic-Jakus, G Juric-Lekic, A Fucic, S Maric and D Serman

Int. J. Dev. Biol. (1999) 43: 843-846

The human placenta becomes haemochorial at the 13th week of pregnancy.

J M Foidart, J Hustin, M Dubois and J P Schaaps

Int. J. Dev. Biol. (1992) 36: 451-453

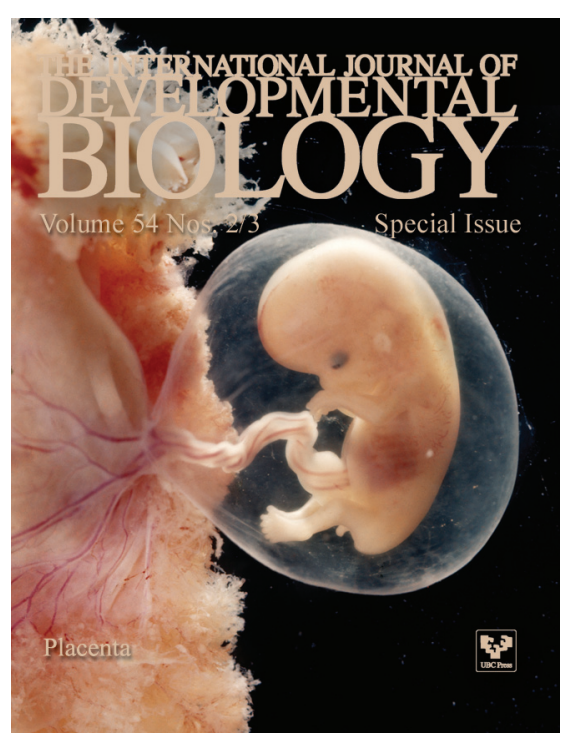

5 yr ISI Impact Factor $(2008)=3.271$

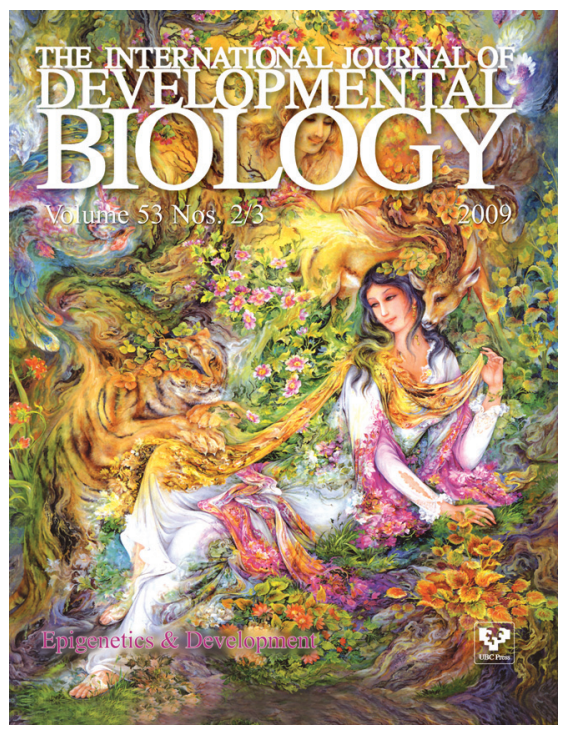

